\title{
Gambaran pengetahuan dan praktik menyusun menu sarapan pada orang tua siswa SDIT Al-Fahmi Palu
}

Description of knowledge and putting healthy breakfast on menu in parents of students of SDIT Al-Fahmi Palu

\author{
Hermiyanty ${ }^{1}$, Siti Ika Fitrasyah ${ }^{2}$, Ummu Aiman ${ }^{2}$, Muhammad Rizki Ashari ${ }^{1}$ \\ ${ }^{1}$ Program Studi Kesehatan Masyarakat, Fakultas Kesehatan Masyarakat, Universitas Tadulako, \\ ${ }^{2}$ Program Studi Gizi, Fakultas Kesehatan Masyarakat, Universitas Tadulako
}

E-mail: ikafitrasyah@untad.ac.id

Naskah diterima : 11-05-2018

Naskah diterbitkan:18-06-2018

\begin{abstract}
Background \& Objective: One of the messages from the 13 General Messages of Nutrition is get used to breakfast. However, there are still many Indonesians who do not have breakfast. This study aimed to see the description of knowledge level of breakfast and the description of the application of balanced nutrition principle on the breakfast menu in the parents of SDIT Al-Fahmi Palu students. Materials and Methods: Material used artificial plates, paperboard and double tip. The research design was cross sectional, was conducted at SDIT Al-Fahmi Palu on September 5, 2017 witth respondents who followed the research were 51. Types of data used were frequency of knowledge level, frequency of respondents who correctly answered the knowledge questionnaire, and the application of balanced nutrition principle on the breakfast menu then analyzed desctriptively. Results: Overall of respondents had a good knowledge. It appears that the most answered questions was "how it can be done to overcome a child with difficulty eating breakfast" $(47.1 \%)$. In contrast, when the practice of menu preparation was obtained on the first day, from 12 groups only 1 group who had applied the principle of balanced nutrition in composing menu, on the 2nd day only 2 groups $(16,7 \%)$ who have applied, and on the third day none of the groups who have applied. Conclusion: It is found that all respondents had a good level of knowledge, but in practice the whole of the groups who have not applied balanced nutrition principle in composing menu.
\end{abstract}

Keywords : healthy breakfast menu, knowledge of parents

\section{ABSTRAK}

Pendahuluan \& Tujuan: Salah satu isi pesan dari 13 PUGS adalah biasakan sarapan pagi. Namun, masih banyak penduduk Indonesia yang tidak sarapan. Kampanye sarapan sehat harus dilaksanakan oleh semua pihak. Penelitian ini bertujuan untuk melihat gambaran tingkat pengetahuan sarapan dan gambaran penerapan prinsip gizi seimbang pada susunan menu sarapan pada orang tua siswa SDIT Al-Fahmi Palu. Bahan dan Metode: Bahan menggunakan piring tiruan yang terbuat dari kertas, kertas karton dan double tip. Desain penelitian adalah deskriptif. Penelitian dilaksanakan di SDIT Al-Fahmi Kota Palu pada tanggal 5 September 2017. Responden yang mengikuti penelitian sebanyak 51 orang. Jenis data yang digunakan dalam penelitian berupa data frekuensi tingkat pengetahuan sarapan responden, frekuensi responden yang menjawab benar kuesioner pengetahuan sarapan, dan penerapan prinsip gizi seimbang pada susunan menu sarapan selama tiga hari menggunakan media piring tiruan. Hasil: Keseluruhan (100\%) responden memiliki tingkat pengetahuan baik. Namun sebaliknya, ketika dilakukan praktik penyusunan menu diperoleh pada hari ke-1, dari 12 kelompok hanya 1 kelompok $(8,3 \%)$ yang sudah menerapkan prinsip gizi seimbang dalam praktik menyusun menu sarapan, pada hari ke-2 hanya 2 kelompok $(16,7 \%)$ yang sudah menerapkan prinsip gizi seimbang dalam praktik menyusun menu sarapan, dan pada hari ke-3 tidak ada satupun kelompok yang sudah menerapkan prinsip gizi seimbang dalam praktik menyusun menu sarapan. Kesimpulan: Keseluruhan responden telah memiliki tingkat pengetahuan baik, namun pada praktinya hampir keseluruhan dari 12 kelompok responden yang belum menerapkan prinsip gizi seimbang dalam praktik menyusun menu sarapan.

Kata Kunci : menu sarapan sehat, pengetahuan orang tua 


\section{A. Pendahuluan}

Permasalahan gizi di Indonesia seakan tidak ada habisnya. Indonesia masih memiliki beban untuk mengentaskan stunting dan wasting yang masih tinggi. Di saat yang sama, Indonesia memiliki masalah baru, yakni angka prevalensi obesitas yang juga terus meningkat. Hal ini membuat Indonesia memiliki masalah undernutrition dan over nutrition dalam waktu bersamaan atau yang disebut dengan double burden of malnutrition atau beban ganda gizi salah. Beban ganda gizi salah ini dapat terjadi di tingkat individu, rumah tangga, dan populasi di sepanjang daur kehidupan manusia (NF, 2017). Sebanyak $30,7 \%$ anak Indonesia memiliki status gizi pendek dan sangat pendek, sebanyak $11,2 \%$ anak yang tergolong kurus dan sangat kurus, Sementara, di sisi lain sebanyak $18,8 \%$ anak yang tergolong gemuk dan sangat gemuk (Balitbangkes Kemenkes RI, 2013).

Salah satu isi pesan dari 13 Pesan Umum Gizi Seimbang (PUGS) dan Keluarga Sadar Gizi (Kadarzi) adalah biasakan sarapan pagi. Namun, masih banyak penduduk Indonesia yang tidak sarapan. Melewatkan sarapan telah menjadi kebiasaan di zaman modern karena perubahan gaya hidup keluarga. Sarapan dianggap oleh banyak orang sebagai "makanan paling penting", karena asupan makanan yang cukup di pagi hari membantu menjamin proporsi kebutuhan gizi tubuh terpenuhi di sepanjang hari. Data Riset Kesehatan Dasar (Riskesdas) tahun 2010 menyatakan bahwa 26,1\% anak sekolah dasar (SD) hanya sarapan dengan air minum dan 44,6\% anak SD yang sarapan hanya memperoleh asupan energi kurang dari 15\% kebutuhannya (Badan Penelitian Dan Pengembangan Kkesehatan Kementerian Kesehatan Republik Indonesia, 2010).

Anak yang belajar di sekolah pada pagi hari dengan perut kosong sebagian disebabkan oleh glukosa darah yang rendah (Adolphus, Lawton, \& Dye, 2013). Sarapan secara positif memengaruhi perilaku, kognitif terutama memori, kinerja sekolah anak, fungsi psikososial, dan suasana hati (Deshmukh-Taskar et al., 2010; Rampersaud, Pereira, Girard, Adams, \& Metzl, 2005). Untuk mempertahankan tingkat metabolisme anak yang tinggi, dibutuhkan pasokan energi yang kontinyu yang berasal dari glukosa tubuh. Anak yang terbiasa sarapan lebih cenderung memiliki asupan gizi yang baik termasuk asupan serat dan karbohidrat total yang lebih tinggi, dan menurunkan kadar lemak total dan kolesterol (Deshmukh-Taskar et al., 2010). Peningkatan konsumsi roti, ngemil di antara waktu makan dan melewatkan sarapan pada anak ditemukan terkait dengan lingkar pinggang (Kuriyan et al., 2012). Pengaruh sarapan terhadap status kesehatan dari waktu ke waktu sangat bermanfaat untuk anak yang memiliki asupan makanan harian yang hampir tidak mencukupi (Huang, Hu, Fan, Liao, $\&$ Tsai, 2010). Rata-rata sebesar 20\% anak melewatkan sarapan secara teratur. Penelitian menunjukkan bahwa anak yang sarapan, meningkatkan prestasi akademik serta menurunkan ketidakhadiran dan keterlambatan siswa secara signifikan (Das, 2016; Rampersaud et al., 2005).

Sarapan secara signifikan berkontribusi terhadap kecukupan gizi makanan. Sarapan harus mencakup berbagai makanan sehat yang memiliki nilai gizi tinggi namun tidak memberikan energi berlebih (Rampersaud et al., 2005). Kampanye sarapan sehat khususnya mengenai sarapan harus dilaksanakan oleh semua pihak yaitu anak-anak, ibu, guru, dan tokoh masyarakat. Hal ini diperlukan agar kebiasaan sarapan selalu diterapkan sehingga asupan zat gizi dapat terpenuhi. Berdasarkan literatur terkait sehingga dapat disimpulkan bahwa penelitian gambaran pengetahuan sarapan sehat pada orang tua siswa SDIT Al-Fahmi Kota Palu layak untuk dilakukan.

Tujuan dari penelitian adalah untuk melihat gambaran tingkat pengetahuan sarapan dan gambaran penerapan prinsip gizi seimbang pada susunan menu sarapan menggunakan media piring tiruan pada orang tua siswa SDIT AlFahmi Kota Palu. 


\section{B. BAHAN DAN METODE}

Alat yang digunakan berupa gunting dan printer serta bahan berupa piring tiruan terbuat dari kertas berdiameter 12 $\mathrm{cm}$, kertas karton dan double tip. Beberapa gambar bahan pangan (sehat dan tidak sehat) dicetak kemudian digunting sesuai bentuknya kemudian di belakangnya telah direkatkan double tip.

\section{Desain}

Desain penelitian menggunakan cross sectional. Penelitian dilaksanakan di Sekolah Dasar Islam Terpadu (SDIT) AlFahmi Kota Palu, Provinsi Sulawesi Tengah pada tanggal 5 September 2017.

\section{Populasi dan Sampel}

Populasi dalam penelitian ini adalah seluruh orang tua siswa Kelas 1-6 SDIT Al-Fahmi Kota Palu. Berdasarkan hasil perhitungan menggunakan rumus, adapun besar sampel penelitian sebanyak 43 orang dengan estimasi drop out 10\% adalah 47 orang yang ditentukan dengan menggunakan rumus sampel sebagai berikut:

$$
\begin{aligned}
& n=\frac{Z_{1-\alpha / 2}^{2} p(1-p) N}{d^{2}(N-1)+Z_{1-\alpha / 2}^{2} p(1-p)} \\
\mathrm{n} & =\text { sampel minimal } \\
Z_{1-\alpha / 2}^{2}= & 1,96^{2} \\
\mathrm{p} & =0,03(\text { Kalsum \& Halim, 2016) } \\
\mathrm{d} & =0,05 \\
\mathrm{~N} & =
\end{aligned}
$$
Fahmi Kota Palu)

Kriteria responden meliputi, responden merupakan orang tua/wali siswa SDIT Al-Fahmi Kota Palu, dapat membaca dan menulis, orang tua/wali mengasuh anaknya sendiri, dan bersedia mengikuti penelitian. Responden yang telah mengikuti penelitian sebanyak 51 orang.

\section{Pengumpulan Data}

Jenis data yang digunakan dalam penelitian berupa data primer yang meliputi data frekuensi tingkat pengetahuan sarapan responden, frekuensi responden yang menjawab benar kuesioner pengetahuan sarapan, dan penerapan prinsip gizi seimbang pada susunan menu sarapan selama tiga hari menggunakan media piring tiruan. Kemudian responden diarahkan untuk memilih beberapa gambar bahan pangan dan menyusun menu yang menjadi pilihannya seperti ketika membuat menu sarapan sehat untuk anak-anak mereka. Sebanyak 51 responden dibagi menjadi 12 kelompok. Sarapan sehat adalah sarapan yang telah memenuhi unsurunsur gizi seimbang. Dikatakan seimbang ketika jumlah antar kelompok pangan (pangan pokok, lauk-pauk, sayur dan buah) setara, dimana porsi untuk pangan pokok sebanyak 3-8 porsi (100/3\%), lauk dan pauk masing-masing sebanyak 2-3 porsi $(100 / 3 \%)$, serta sayur dan buah masing-masing sebanyak 3-5 porsi dan 23 porsi (100/3\%). Konsumsi pangan untuk sekali makan digambarkan dengan "Piring Makanku : Porsi Sekali Makan"(Kementerian Kesehatan Republik Indonesia, 2014b). Piring tiruan dibuat semirip mungkin dengan "Piring Makanku" dan dapat dilihat pada Gambar 1 di bawah ini. Daftar nama pangan yang disediakan untuk dipilih responden terdiri atas pangan pokok (sumber karbohidrat) : beras, jagung, kentang, roti tawar, ubi jalar, dan mi; lauk dan pauk (sumber protein dan lemak) : ikan, daging, ayam, telur ayam, udang, cumi, kepiting, tempe, tahu, dan kacang-kacangan; sayuran dan buah (vitamin, mineral, serat, dan air) : daun sawi, bayam, kangkung, kubis, asparagus, rebung, lobak, wortel, kembang kol, daun kelor, brokoli, labu siam, daun papaya, tomat, terung, alvokat, apel, anggur, delima, langsat, melon, jambu merah, jeruk malang, kiwi, kurma, lemon, labu kuning, manga, manggis, markisa, nanas, cempedak, nangka, buah naga, pepaya, pisang, pir, salak, rambutan, semangka, sawo, serikaya, sirsak, dan stroberi.

\section{Analisis Data}

Proses pengolahan data meliputi kegiatan editing, coding, entry dan cleaning. Data frekuensi tingkat pengetahuan sarapan sehat responden di SDIT Al-Fahmi Kota Palu dikategorikan sebagai berikut (Budiman \& Riyanto, 2013).

1. Tingkat pengetahuan dikatakan baik jika responden mampu menjawab pernyataan pada kuesioner dengan benar sebesar $\geq 75 \%$ yaitu dengan 
skor $\geq 15$.

2. Tingkat pengetahuan dikatakan cukup jika responden mampu menjawab pernyataan pada kuesioner dengan benar sebesar 56-74\% yaitu dengan skor 12-14.

3. Tingkat pengetahuan dikatakan kurang jika responden mampu menjawab pernyataan pada kuesioner dengan benar sebesar < 55\% yaitu dengan skor $<12$.

Data frekuensi responden yang menjawab benar kuesioner pengetahuan sarapan sehat terdiri dari 20 pertanyaan terkait sarapan sehat meliputi pertanyaan definisi makanan bergizi, pernyataan mengenai pesan gizi seimbang, makanan yang dapat memenuhi kebutuhan gizi, kebiasaan sarapan setiap pagi, kesesuaian menu makanan dan usia dan kebutuhan gizi anak, zat-zat gizi yang terdapat dalam makanan, contoh menu gizi seimbang, fungsi protein, zat gizi yang terkandung dalam sayuran dan buahbuahan, sumber makanan asam lemak esensial omega-3, manfaat sarapan pada anak, waktu sarapan yang baik pada anak, akibat jika anak tidak sarapan, akibat jika anak kekurangan energi, keharusan pergantian menu sarapan pada anak, contoh menu sarapan yang seimbang, minuman yang tidak baik dikonsumsi ketika sarapan, cara yang dapat dilakukan untuk mengatasi anak yang susah sarapan, waktu yang baik untuk anak sarapan, dan akibat jika anak kekurangan gizi.
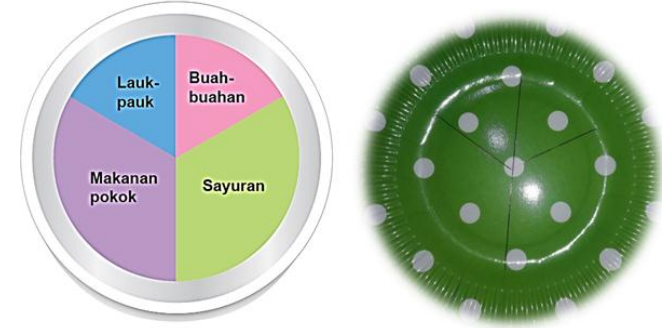

Gambar 1 Piring Makanku : Porsi Sekali Makan dan Piring Tiruan

Data susunan menu sarapan selama tiga hari menggunakan media piring tiruan responden terdiri dari masingmasing tiga piring yang di dalamnya sudah tersaji contoh menu sarapan sehat yang disusun oleh responden. Penerapan prinsip gizi seimbang dalam praktik menyusun menu sarapan kemudian dikategorikan menjadi responden yang belum dan sudah menerapkan gizi seimbang dalam menyusun menu sarapan sehat Analisis data dilakukan secara deskriptif.

\section{HASIL}

\section{Tingkat Pengetahuan Sarapan Responden di SDIT Al-Fahmi Kota Palu}

Berdasarkan Tabel 1, dari 51 responden tampak bahwa keseluruhan $(100 \%)$ responden memiliki tingkat pengetahuan baik.

Tabel 1 Tingkat Pengetahuan Sarapan Sehat Responden di SDIT Al-Fahmi Kota Palu

\begin{tabular}{lcc}
\hline Tingkat Pengetahuan & n (51) & \% (100) \\
\hline Baik & 51 & 100,0 \\
Cukup & 0 & 0,0 \\
Kurang & 0 & 0,0 \\
\hline
\end{tabular}

Responden yang Menjawab Benar Kuesioner Pengetahuan Sarapan Sehat

Pada Tabel 2, dari 20 pertanyaan tampak bahwa pertanyaan yang paling banyak terjawab dengan benar oleh responden adalah pertanyaan tentang cara yang dapat dilakukan untuk mengatasi anak yang susah sarapan dengan persentase sebesar $47,1 \%$. Berdasarkan opsi pertanyaan tersebut, terdapat tiga pilihan jawaban yang terdiri dari opsi memberi imbalan kepada anak agar mau sarapan, membiasakan bangun pagi, dan memarahi anak yang tidak sarapan. Sementara itu, sebanyak empat pertanyaan dengan jawaban benar paling banyak meliputi pertanyaan contoh menu gizi seimbang, manfaat sarapan pada anak, waktu sarapan yang baik pada anak, dan akibat jika anak kekurangan gizi dengan persentase masing-masing sebesar $100 \%$.

\section{Hasil Praktik Menyusun Menu Sarapan} Sehat Selama Tiga Hari Menggunakan Media Piring Tiruan

Analisis susunan menu sarapan sehat selama tiga hari menggunakan media piring tiruan responden berdasarkan prinsip gizi seimbang dapat dilihat pada Tabel 3. Hasil pengukuran tingkat pengetahuan responden, ditemukan dari 51 responden, sebesar $100 \%$ responden sudah memiliki tingkat pengetahuan baik. Kelompok 8 pada hari 2 telah menyusun menu yang seimbang $(\mathrm{KH}$ : beras; P dan L : ikan dan tempe; serta V, M, S, dan A : jeruk, kiwi, dan kangkung). 
Kelompok 10 pada hari 1 dan 2 juga telah berhasil menyusun menu yang seimbang, yang meliputi menu hari 1 : (KH : beras; $\mathrm{P}$ dan L : ikan dan tempe; serta V, M, S, dan A : kangkung, labu kuning, dan pepaya) dan menu hari 2 : (KH : kentang; $\mathrm{P}$ dan $\mathrm{L}$ : tahu dan udang; serta $\mathrm{V}, \mathrm{M}, \mathrm{S}$, dan A : kurma, wortel, brokoli, semangka, dan jeruk).

Tabel 2 Responden yang Menjawab Benar Kuesioner Pengetahuan Sarapan Sehat

\begin{tabular}{|c|c|c|c|}
\hline \multirow[t]{2}{*}{ No. } & \multirow[t]{2}{*}{ Pertanyaan } & \multicolumn{2}{|c|}{$\begin{array}{c}\text { Responden } \\
\text { yang } \\
\text { Menjawab } \\
\text { Pertanyaan } \\
\text { dengan } \\
\text { Benar }\end{array}$} \\
\hline & & $\mathbf{n}$ & $\%$ \\
\hline 1 & Definisi makanan bergizi & 50 & 98,0 \\
\hline 2 & $\begin{array}{l}\text { Pernyataan mengenai } \\
\text { pesan gizi seimbang }\end{array}$ & 47 & 92,2 \\
\hline 3 & $\begin{array}{l}\text { Makanan yang dapat } \\
\text { memenuhi kebutuhan gizi }\end{array}$ & 50 & 98,0 \\
\hline 4 & $\begin{array}{l}\text { Kebiasaan sarapan setiap } \\
\text { pagi }\end{array}$ & 44 & 86,3 \\
\hline 5 & $\begin{array}{l}\text { Kesesuaian menu makanan } \\
\text { dan usia dan kebutuhan } \\
\text { gizi anak }\end{array}$ & 44 & 86,3 \\
\hline 6 & $\begin{array}{l}\text { Zat-zat gizi yang terdapat } \\
\text { dalam makanan }\end{array}$ & 30 & 58,8 \\
\hline 7 & Contoh menu gizi seimbang & 51 & 100,0 \\
\hline 8 & Fungsi protein & 29 & 56,9 \\
\hline 9 & $\begin{array}{l}\text { Zat gizi yang terkandung } \\
\text { dalam sayuran dan buah- } \\
\text { buahan }\end{array}$ & 40 & 78,4 \\
\hline 10 & $\begin{array}{l}\text { Sumber makanan asam } \\
\text { lemak esensial omega-3 }\end{array}$ & 47 & 92,2 \\
\hline 11 & $\begin{array}{l}\text { Manfaat sarapan pada } \\
\text { anak }\end{array}$ & 51 & 100,0 \\
\hline 12 & $\begin{array}{l}\text { Waktu sarapan yang baik } \\
\text { pada anak }\end{array}$ & 51 & 100,0 \\
\hline 13 & $\begin{array}{l}\text { Akibat jika anak tidak } \\
\text { sarapan }\end{array}$ & 46 & 90,2 \\
\hline 14 & $\begin{array}{l}\text { Akibat jika anak } \\
\text { kekurangan energi }\end{array}$ & 50 & 98,0 \\
\hline 15 & $\begin{array}{l}\text { Keharusan pergantian } \\
\text { menu sarapan pada anak }\end{array}$ & 47 & 92,2 \\
\hline 16 & $\begin{array}{l}\text { Contoh menu sarapan yang } \\
\text { seimbang }\end{array}$ & 39 & 76,5 \\
\hline 17 & $\begin{array}{l}\text { Minuman yang tidak baik } \\
\text { dikonsumsi ketika sarapan }\end{array}$ & 27 & 52,9 \\
\hline 18 & $\begin{array}{l}\text { Cara yang dapat dilakukan } \\
\text { untuk mengatasi anak } \\
\text { yang susah sarapan }\end{array}$ & 24 & 47,1 \\
\hline 19 & $\begin{array}{l}\text { Waktu yang baik untuk } \\
\text { anak sarapan }\end{array}$ & 46 & 90,2 \\
\hline 20 & $\begin{array}{l}\text { Akibat jika anak } \\
\text { kekurangan gizi }\end{array}$ & 51 & 100,0 \\
\hline
\end{tabular}

Susunan menu secara lengkap dapat dilihat pada Tabel 3. Sementara kelompok yang lain masih terdapat kesalahan dalam menyusun menu seimbang seperti pangan pokok berlebih, lauk berlebih, pauk tidak tersedia, sayuran tidak tersedia, dan lainnya. Untuk lebih lengkapnya dapat dilihat pada Tabel 4 . Setelah dianalisis, maka dapat disimpulkan pada hari ke-1, dari 12 kelompok hanya 1 kelompok $(8,3 \%)$ yang sudah menerapkan prinsip gizi seimbang dalam praktik menyusun menu sarapan, pada hari ke-2 hanya 2 kelompok $(16,7 \%)$ yang sudah menerapkan, dan pada hari ke-3 tidak ada satupun kelompok yang sudah menerapkan. Hasil lebih lengkap dapat dilihat pada Tabel 5

\section{PEMBAHASAN}

Berdasarkan Tabel 1, keseluruhan $(100 \%)$ responden memiliki tingkat pengetahuan baik. Berdasarkan penelitian sebelumnya terdapat hubungan yang bermakna antara pengetahuan gizi anak dengan kebiasaan sarapan $(\mathrm{p}<0,05)$ (Sofianita, Arini, \& Meiyetriani, 2015). Selain itu, persentase subjek yang selalu sarapan lebih banyak pada subjek yang tingkat pengetahuan gizinya baik $(62,1 \%)$ (Ariyanti, 2005). Jika pengetahuan gizi seseorang tinggi maka cenderung untuk memilih makanan yang lebih murah dengan nilai gizi yang tinggi (Husaini, 1992). Peningkatan pengetahuan ini juga dimungkinkan karena terdapat kesadaran orang tua siswa setelah mendapatkan informasi dari berbagai media baik dari internet, lingkungan sekolah, keluarga, atau dari masyarakat tempat anak-anak beraktivitas.
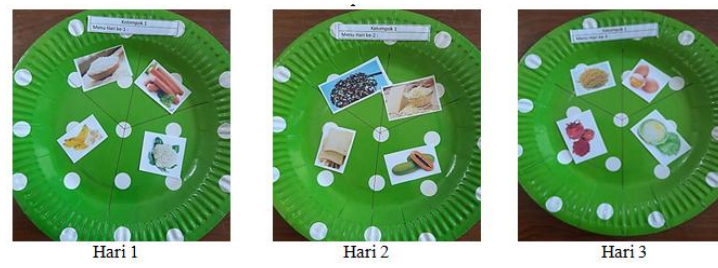

Gambar 2. Hasil Susunan Menu Sarapan Sehat

Selama Tiga Hari Kelompok 1 Menggunakan Media Piring Tiruan Responden

Ibu adalah orang yang bertanggung jawab untuk memberi makan anak-anak mereka dan secara bersamaan menciptakan praktik makan anak-anak mereka. Status gizi anak-anak yang buruk mencerminkan ketidakseimbangan dalam asupan makanan dan dipengaruhi oleh berbagai faktor lingkungan dan sosial ekonomi seperti keluarga 
berpenghasilan rendah (Adnan \& Muniandy, 2012; Hong, Banta, \& Betancourt, 2006), tingkat pendidikan ibu (Adnan \& Muniandy, 2012; Hien \& Hoa, 2009; Pongou, Ezzati, \& Salomon, 2005), urutan kelahiran anak dan durasi menyusui (Adnan \& Muniandy, 2012; Kamal, 2011). Ibu perlu memiliki pengetahuan memadai melalui penyerapan informasi dari media cetak maupun visual. Perilaku gizi harus didasari oleh pengetahuan gizi yang baik untuk mendorong perilaku ibu dalam menyiapkan sarapan sehat bagi anaknya. Pengetahuan yang baik dapat diperoleh ketika diberikan pendidikan gizi (Fatmah, 2015; Yin et al., 2009).

Tabel 3 Daftar Susunan Menu Sarapan Sehat Selama Tiga Hari Menggunakan Media Piring Tiruan Responden

\begin{tabular}{|c|c|c|c|}
\hline \multirow[t]{2}{*}{ Kelompok } & \multicolumn{3}{|c|}{ Daftar Susunan Menu Sarapan Sehat Responden } \\
\hline & Hari 1 & Hari 2 & Hari 3 \\
\hline 1 & $\begin{array}{ll} & \mathrm{KH}: \text { Beras } \\
\text { - } & \mathrm{P} \text { dan } \mathrm{L}: \text { sosis } \\
\text { - } & \mathrm{V}, \mathrm{M}, \mathrm{S}, \text { dan } \mathrm{A}: \text { kembang kol } \\
& \text { dan pisang } \\
\end{array}$ & $\begin{array}{ll}\text { - } & \mathrm{KH}: \text { roti tawar dan coklat butir } \\
\text { - } & \mathrm{P} \text { dan } \mathrm{L}: \text { keju } \\
\text { - } & \mathrm{V}, \mathrm{M}, \mathrm{S}, \text { dan } \mathrm{A}: \text { buah pepaya }\end{array}$ & $\begin{array}{ll} & \mathrm{KH}: \mathrm{mi} \\
\text { - } & \mathrm{P} \text { dan } \mathrm{L}: \text { telur } \\
\text { - } & \mathrm{V}, \mathrm{M}, \mathrm{S}, \text { dan } \mathrm{A}: \text { sayur kubis dan } \\
& \text { pisang }\end{array}$ \\
\hline 2 & $\begin{array}{ll}\text { - } & \mathrm{KH} \text { : roti tawar } \\
\text { - } & \mathrm{P} \text { dan } \mathrm{L}: \text { keju dan selai kacang } \\
\text { - } & \mathrm{V}, \mathrm{M}, \mathrm{S}, \text { dan } \mathrm{A} \text { : selai nanas }\end{array}$ & $\begin{array}{ll}\text { - } & \mathrm{KH}: \text { beras dan jagung } \\
\text { - } & \mathrm{P} \text { dan } \mathrm{L}: \text { ikan dan tempe } \\
\text { - } & \mathrm{V}, \mathrm{M}, \mathrm{S}, \text { dan } \mathrm{A}: \text { sayur daun } \\
& \text { sawi dan pisang }\end{array}$ & $\begin{array}{ll}\text { - } & \mathrm{KH}: \text { kentang } \\
\text { - } & \text { P dan L : telur dan kacang- } \\
& \text { kacangan } \\
\text { - } & \mathrm{V}, \mathrm{M}, \mathrm{S}, \text { dan } \mathrm{A}: \text { kurma }\end{array}$ \\
\hline 3 & $\begin{array}{l}\text { - } \mathrm{KH}: \text { beras, kentang } \\
\text { - } \mathrm{P} \text { dan } \mathrm{L}: \text { tempe, udang } \\
\text { - } \mathrm{V}, \mathrm{M}, \mathrm{S}, \text { dan } \mathrm{A}: \text { pepaya, pisang, } \\
\text { tomat, dan wortel }\end{array}$ & $\begin{array}{ll}\text { - } & \mathrm{KH}: \text { coklat butir dan roti } \\
& \text { tawar } \\
\text { - } & \mathrm{P} \text { dan } \mathrm{L}: \text { mentega dan keju } \\
\text { - } & \mathrm{V}, \mathrm{M}, \mathrm{S}, \text { dan } \mathrm{A}: \text { pir dan selai } \\
& \text { nanas }\end{array}$ & $\begin{array}{ll}\text { - } & \mathrm{KH}: \mathrm{mi} \\
\text { - } & \mathrm{P} \text { dan } \mathrm{L}: \text { telur } \\
\text { - } & \mathrm{V}, \mathrm{M}, \mathrm{S}, \text { dan } \mathrm{A}: \text { kubis, brokoli, } \\
& \text { anggur dan jeruk }\end{array}$ \\
\hline 4 & $\begin{array}{ll}\text { - } & \mathrm{KH}: \text { roti tawar, selai coklat } \\
\text { - } & \text { P dan L : keju } \\
\text { - } & \mathrm{V}, \mathrm{M}, \mathrm{S}, \text { dan } \mathrm{A}: \text { apel }\end{array}$ & $\begin{array}{ll}\text { - } & \mathrm{KH}: \text { beras } \\
\text { - } & \mathrm{P} \text { dan } \mathrm{L}: \text { ikan dan sosis } \\
\text { - } & \mathrm{V}, \mathrm{M}, \mathrm{S}, \text { dan } \mathrm{A}: \text { pepaya dan } \\
& \text { kubis }\end{array}$ & $\begin{array}{ll} & \mathrm{KH}: \text { kentang } \\
\text { - } & \mathrm{P} \text { dan L : ayam dan telur } \\
\text { - } & \mathrm{V}, \mathrm{M}, \mathrm{S}, \text { dan } \mathrm{A}: \text { pisang }\end{array}$ \\
\hline 5 & $\begin{array}{l}\text { - } \mathrm{KH} \text { : beras } \\
\text { - } \mathrm{P} \text { dan L : telur, tempe, dan sosis } \\
\text { - } \mathrm{V}, \mathrm{M}, \mathrm{S} \text {, dan A : brokoli, pisang }\end{array}$ & $\begin{array}{ll}\text { - } & \mathrm{KH}:- \\
\text { - } & \mathrm{P} \text { dan L : - } \\
\text { - } & \mathrm{V}, \mathrm{M}, \mathrm{S}, \text { dan A : kurma }\end{array}$ & $\begin{array}{ll}\text { - } & \mathrm{KH} \text { : roti tawar dan selai coklat } \\
\text { - } & \mathrm{P} \text { dan } \mathrm{L}: \text { mentega } \\
\text { - } & \mathrm{V}, \mathrm{M}, \mathrm{S}, \text { dan } \mathrm{A}: \text { pir, kiwi, dan } \\
& \text { apel }\end{array}$ \\
\hline 6 & $\begin{array}{ll}\text { - } & \mathrm{KH}: \text { beras } \\
\text { - } & \mathrm{P} \text { dan } \mathrm{L}: \text { ikan dan tahu } \\
\text { - } & \mathrm{V}, \mathrm{M}, \mathrm{S}, \text { dan } \mathrm{A}: \text { wortel }\end{array}$ & $\begin{array}{ll}\text { - } & \mathrm{KH} \text { : roti tawar dan coklat butir } \\
\text { - } & \mathrm{P} \text { dan } \mathrm{L}: \text { keju dan mentega } \\
\text { - } & \mathrm{V}, \mathrm{M}, \mathrm{S}, \text { dan } \mathrm{A}: \text { - } \\
\end{array}$ & $\begin{array}{ll}\text { - } & \mathrm{KH}: \text { jagung } \\
\text { - } & \mathrm{P} \text { dan L : daging } \\
\text { - } & \mathrm{V}, \mathrm{M}, \mathrm{S}, \text { dan } \mathrm{A}: \text { pir }\end{array}$ \\
\hline 7 & $\begin{array}{l}\text { - } \mathrm{KH} \text { : kentang dan beras } \\
\text { P dan L : tempe } \\
\text { - } \mathrm{V}, \mathrm{M}, \mathrm{S}, \text { dan A : tomat, pisang, } \\
\text { brokoli, dan wortel }\end{array}$ & $\begin{array}{l}\text { KH : coklat butir, ubi jalar, } \\
\text { jagung, dan roti tawar } \\
\text { - } \mathrm{P} \text { dan L : keju dan sosis } \\
\text { - } \mathrm{V}, \mathrm{M}, \mathrm{S} \text {, dan A : papaya dan } \\
\text { kurma }\end{array}$ & $\begin{array}{l}\text { - } \mathrm{KH}: \mathrm{mi} \\
\text { - } \mathrm{P} \text { dan L : ayam, telur, dan tahu } \\
\text { - } \mathrm{V}, \mathrm{M}, \mathrm{S}, \text { dan A : daun sawi, } \\
\text { lobak, buah naga, dan manggis }\end{array}$ \\
\hline 8 & $\begin{array}{ll}\text { - } & \mathrm{KH}: \mathrm{mi} \\
\text { - } & \mathrm{P} \text { dan } \mathrm{L}: \text { ayam } \\
\text { - } & \mathrm{V}, \mathrm{M}, \mathrm{S}, \text { dan } \mathrm{A}: \text { buah naga, } \\
\text { selai nanas, papaya, tomat, } \\
\text { wortel, dan brokoli }\end{array}$ & $\begin{array}{ll} & \mathrm{KH}: \text { beras } \\
\text { - } & \mathrm{P} \text { dan } \mathrm{L}: \text { ikan dan tempe } \\
\text { - } & \mathrm{V}, \mathrm{M}, \mathrm{S}, \text { dan } \mathrm{A}: \text { jeruk, kiwi, } \\
\text { dan kangkung }\end{array}$ & $\begin{array}{l}\text { - } \mathrm{KH} \text { : roti tawar dan selai coklat } \\
\text { P dan L : selai kacang, kacang- } \\
\text { kacangan, dan keju } \\
\text { - } \quad \mathrm{V}, \mathrm{M}, \mathrm{S}, \text { dan } \mathrm{A} \text { : apel, pisang, } \\
\text { kurma, kubis, dan sawi }\end{array}$ \\
\hline 9 & $\begin{array}{ll} & \mathrm{KH}: \text { beras } \\
\text { - } & \mathrm{P} \text { dan L : ikan } \\
\text { - } & \mathrm{V}, \mathrm{M}, \mathrm{S}, \text { dan A : wortel dan } \\
& \text { pisang }\end{array}$ & $\begin{array}{ll}\text { - } & \mathrm{KH}: \text { roti tawar dan selai coklat } \\
\text { - } & \mathrm{P} \text { dan } \mathrm{L}: \text { sosis } \\
\text { - } & \mathrm{V}, \mathrm{M}, \mathrm{S}, \text { dan } \mathrm{A}: \text { apel }\end{array}$ & $\begin{array}{ll}\text { - } & \mathrm{KH} \text { : ubi jalar dan kentang } \\
\text { - } & \text { P dan L : daging } \\
\text { - } & \mathrm{V}, \mathrm{M}, \mathrm{S}, \text { dan } \mathrm{A}: \text { brokoli dan } \\
& \text { delima }\end{array}$ \\
\hline 10 & $\begin{array}{l}\text { - } \mathrm{KH} \text { : beras } \\
\text { - } \mathrm{P} \text { dan } \mathrm{L}: \text { ikan dan tempe } \\
\text { - } \mathrm{V}, \mathrm{M}, \mathrm{S}, \text { dan A : kangkung, labu } \\
\text { kuning, dan pepaya }\end{array}$ & $\begin{array}{ll}\text { - } & \mathrm{KH}: \text { kentang } \\
\text { - } & \text { P dan L : tahu dan udang } \\
\text { - } & \mathrm{V}, \mathrm{M}, \mathrm{S}, \text { dan A : kurma, wortel, } \\
& \text { brokoli, semangka, dan jeruk }\end{array}$ & $\begin{array}{l}\text { KH : roti tawar } \\
\text { P dan } \mathrm{L}: \text { keju, mentega, sosis, } \\
\text { dan telur } \\
\text { V, M, S, dan A : kurma, pisang, } \\
\text { dan daun sawi }\end{array}$ \\
\hline 11 & $\begin{array}{l}\text { - } \mathrm{KH}: \text { beras } \\
\text { - } \mathrm{P} \text { dan } \mathrm{L}: \text { ayam } \\
\text { - } \mathrm{V}, \mathrm{M}, \mathrm{S}, \text { dan } \mathrm{A} \text { : wortel, } \\
\text { kangkung, tomat, anggur, dan } \\
\text { jeruk }\end{array}$ & $\begin{array}{l}\text { - } \mathrm{KH}: \text { roti tawar dan jagung } \\
\text { - } \mathrm{P} \text { dan } \mathrm{L}: \text { keju dan sosis } \\
\text { - } \mathrm{V}, \mathrm{M}, \mathrm{S}, \text { dan } \mathrm{A} \text { : pisang, apel, } \\
\text { kangkung, dan lobak }\end{array}$ & $\begin{array}{l}\text { - } \mathrm{KH}: \text { kentang } \\
\text { - } \mathrm{P} \text { dan } \mathrm{L}: \text { daging, tahu, tempe } \\
\text { - } \mathrm{V}, \mathrm{M}, \mathrm{S}, \text { dan } \mathrm{A}: \text { buah naga, } \\
\text { stroberi, jambu merah, terung, } \\
\text { sawi, dan labu siam }\end{array}$ \\
\hline 12 & $\begin{array}{l}\text { - } \mathrm{KH} \text { : beras dan jagung } \\
\text { P dan L : ayam, udang, dan } \\
\text { tempe } \\
\text { - } \mathrm{V}, \mathrm{M}, \mathrm{S} \text {, dan A : kangkung, labu } \\
\text { kuning, pepaya, dan jeruk }\end{array}$ & $\begin{array}{l}\text { - } \mathrm{KH}: \text { roti tawar, selai coklat, } \\
\text { dan ubi jalar } \\
\text { - } \mathrm{P} \text { dan } \mathrm{L}: \text { daging dan tahu } \\
\text { - } \mathrm{V}, \mathrm{M}, \mathrm{S}, \text { dan } \mathrm{A}: \text { daun sawi, } \\
\text { semangka, dan mangga }\end{array}$ & $\begin{array}{ll} & \mathrm{KH}: \text { kentang } \\
\text { - } & \mathrm{P} \text { dan } \mathrm{L}: \text { ikan, telur, dan sosis } \\
\text { - } & \mathrm{V}, \mathrm{M}, \mathrm{S}, \text { dan } \mathrm{A}: \text { kubis dan } \\
& \text { pisang }\end{array}$ \\
\hline
\end{tabular}

Tabel 4 Analisis Susunan Menu Sarapan Sehat Selama Tiga Hari Menggunakan Media Piring Tiruan 
Responden Berdasarkan Prinsip Gizi Seimbang

\begin{tabular}{|c|c|c|c|}
\hline \multirow[t]{2}{*}{ Kelompok } & \multicolumn{3}{|c|}{ Daftar Susunan Menu Sarapan Sehat Responden } \\
\hline & Hari 1 & Hari 2 & Hari 3 \\
\hline 1 & - $\quad$ Pauk tidak tersedia & $\begin{array}{ll}\text { - } & \text { Pangan pokok berlebih } \\
\text { - } & \text { Pauk tidak tersedia } \\
\text { - } & \text { Sayuran tidak tersedia }\end{array}$ & - $\quad$ Pauk tidak tersedia \\
\hline 2 & - $\quad$ Sayuran tidak tersedia & - $\quad$ Pangan pokok berlebih & - $\quad$ Sayuran tidak tersedia \\
\hline 3 & - Pangan pokok berlebih & $\begin{array}{ll}\text { - } & \text { Pangan pokok berlebih } \\
\text { - } & \text { Lauk berlebih } \\
\text { - } & \text { Pauk tidak tersedia } \\
\text { - } & \text { Sayuran tidak tersedia }\end{array}$ & - $\quad$ Pauk tidak tersedia \\
\hline 4 & $\begin{array}{ll}\text { - } & \text { Pangan pokok berlebih } \\
\text { - } & \text { Pauk tidak tersedia } \\
\text { - } & \text { Sayuran tidak tersedia }\end{array}$ & - $\quad$ Pauk tidak tersedia & $\begin{array}{ll} & \text { Pauk tidak tersedia } \\
\text { - } & \text { Sayuran tidak tersedia }\end{array}$ \\
\hline 5 & - Lauk berlebih & $\begin{array}{ll}\text { - } & \text { Pangan pokok tidak tersedia } \\
\text { - } & \text { Lauk dan pauk tidak tersedia } \\
\text { - } & \text { Sayuran tidak tersedia } \\
\end{array}$ & $\begin{array}{ll}\text { - } & \text { Pangan pokok berlebih } \\
\text { - } & \text { Pauk tidak tersedia } \\
\text { - } & \text { Sayuran tidak tersedia } \\
\end{array}$ \\
\hline 6 & - Buah tidak tersedia & $\begin{array}{l}\text { - Pangan pokok berlebih } \\
\text { - Lauk berlebih } \\
\text { - Pauk tidak tersedia } \\
\text { - } \text { Buah dan sayuran tidak tersedia }\end{array}$ & $\begin{array}{ll} & \text { Pauk tidak tersedia } \\
\text { - } & \text { Sayuran tidak tersedia }\end{array}$ \\
\hline 7 & $\begin{array}{l}\text { - } \quad \text { Pangan pokok berlebih } \\
\text { - Lauk tidak tersedia }\end{array}$ & $\begin{array}{l}\text { - } \text { Pangan pokok berlebih } \\
\text { - } \quad \text { Lauk berlebih } \\
\text { - } \quad \text { Pauk tidak tersedia } \\
\text { - } \quad \text { Sayuran tidak tersedia }\end{array}$ & - Lauk berlebih \\
\hline 8 & - $\quad$ Pauk tidak tersedia & - Menu sudah seimbang & $\begin{array}{l}\text { - } \quad \text { Pangan pokok berlebih } \\
\text { - } \quad \text { Pauk berlebih }\end{array}$ \\
\hline 9 & - $\quad$ Pauk tidak tersedia & $\begin{array}{l}\text { - } \text { Pangan pokok berlebih } \\
\text { - } \quad \text { Pauk tidak tersedia } \\
\text { - } \quad \text { Sayuran tidak tersedia }\end{array}$ & $\begin{array}{l}\text { - } \quad \text { Pangan pokok berlebih } \\
\text { - } \quad \text { Pauk tidak tersedia }\end{array}$ \\
\hline 10 & - $\quad$ Menu sudah seimbang & - Menu sudah seimbang & $\begin{array}{ll}\text { - } & \text { Lauk berlebih } \\
\text { - } & \text { Pauk tidak tersedia }\end{array}$ \\
\hline 11 & - $\quad$ Pauk tidak tersedia & $\begin{array}{l}\text { - } \quad \text { Pangan pokok berlebih } \\
\text { - } \quad \text { Lauk berlebih } \\
\text { - } \quad \text { Pauk tidak tersedia }\end{array}$ & - Pauk berlebih \\
\hline 12 & $\begin{array}{l}\text { - Pangan pokok berlebih } \\
\text { - Lauk berlebih }\end{array}$ & - Pangan pokok berlebih & $\begin{array}{ll}\text { - } & \text { Lauk berlebih } \\
\text { - } & \text { Pauk tidak tersedia }\end{array}$ \\
\hline
\end{tabular}

Tabel 5 Penerapan Prinsip Gizi Seimbang dalam Praktik Menyusun Menu Sarapan Sehat Responden

\begin{tabular}{|c|c|c|c|c|c|c|}
\hline \multirow{2}{*}{$\begin{array}{c}\text { Penerapan Prinsip Gizi Seimbang dalam Praktik } \\
\text { Menyusun Menu Sarapan Sehat }\end{array}$} & \multicolumn{2}{|c|}{ Hari 1} & \multicolumn{2}{|c|}{ Hari 2} & \multicolumn{2}{|c|}{ Hari 3} \\
\hline & $\mathbf{n}$ & $\%$ & $\mathbf{n}$ & $\%$ & $\mathbf{n}$ & $\%$ \\
\hline Belum Menerapkan Prinsip Gizi Seimbang & 11 & 91,7 & 10 & 83,3 & 12 & 100,0 \\
\hline Sudah Menerapkan Prinsip Gizi Seimbang & 1 & 8,3 & 2 & 16,7 & 0 & 0,0 \\
\hline Total & 12 & 100,0 & 12 & 100,0 & 12 & 100,0 \\
\hline
\end{tabular}

Gizi seimbang adalah susunan pangan sehari-hari yang mengandung zat gizi dalam jenis dan jumlah yang sesuai dengan kebutuhan tubuh, dengan memperhatikan prinsip keanekaragaman pangan, aktivitas fisik, perilaku hidup bersih dan mempertahankan berat badan normal untuk mencegah masalah gizi (Kemenkes RI, 2014a). Energi dari sarapan dianjurkan mencukupi, sekitar $20-25 \%$ dari kebutuhan energi tubuh perhari. Untuk anak-anak berkisar antara 200-300 kalori. Dalam menyusun menu sarapan, perlu diperhatikan kelengkapan gizi yang dikandungnya, terutama karbohidrat, protein, lemak, vitamin, mineral, dan serat. Susunan menu sarapan pagi sebaiknya sama dengan susunan menu siang atau malam, yaitu terdiri dari sumber zat tenaga, zat pembangun, dan sumber zat pengatur. Makan pagi perlu diberikan untuk mencegah hipoglikemia dan supaya anak mudah dalam menerima pelajaran. Jika anak harus belajar dengan baik tiap hari, maka harus mendapatkan sesuatu untuk menahan lapar, dapat berupa sarapan dengan menu lengkap yang disediakan oleh orang tuanya atau sekolah. Sarapan pagi sangat penting karena makanan yang dimakan pada waktu pagi hari sebelum kita melakukan aktivitas dapat memberikan energi bagi tubuh kita (Hardinsyah, 2013).

Persepsi yang cukup tentang sarapan disebabkan oleh penerimaan stimulasi anak dari berbagai sumber informasi tentang sarapan yang dapat diterima oleh mereka. Para responden dianggap memiliki sarapan yang berkualitas 
berdasarkan sajian makanan yang cukup, dimana responden mengonsumsi paling sedikit empat jenis sajian makanan. Anak-anak dapat mengonsumsi beras (sumber karbohidrat) dengan lauk ikan rebus dan pauk tempe goreng (sumber protein), segelas susu (sumber lemak), berbagai sayuran dan buah-buahan berwarna hijau gelap atau non-hijau (zat gizi mikro). Anak-anak lebih bersedia untuk berpartisipasi dalam kegiatan belajar ketika mereka dalam keadaan sehat (Adolphus et al., 2013; Indrasari, Mutalazimah, Kumalasari, \& Buana, 2018; Kawafheh, 2014; Murchu, 2010). Seperti yang telah dijelaskan sebelumnya bahwa memang sarapan memiliki efek positif pada kinerja kognitif anak-anak (Cooper, Bandelow, \& Nevil, 2011; Indrasari et al., 2018; Pivik, Tennal, Chapman, \& Gu, 2012).

Persepsi yang memadai tentang sarapan dengan lebih sedikit variasi sajian makanan dapat disebabkan oleh beberapa faktor. Salah satu faktornya adalah kurangnya makanan yang tersedia untuk sarapan. Hal ini bisa juga karena kurangnya kesediaan responden dalam melakukan tindakan (sarapan) sesuai dengan persepsi yang telah terbentuk dari informasi yang didapat (Indrasari et al., 2018; Mcdonell, Probart, Weirich, Hartman, \& Birkenshaw, 2004). Responden yang memiliki persepsi sarapan yang cukup dengan asupan energi sarapan lebih banyak, yang berarti bahwa responden telah menyadari pentingnya sarapan, tetapi mereka belum mempraktikkannya dalam kehidupan sehari-hari dalam kaitannya dengan jumlah makanan yang harus dikonsumsi untuk sarapan.

Pada Tabel 4 dan 5 tampak bahwa hari ke-1, dari 12 kelompok hanya 1 kelompok $(8,3 \%)$ yang sudah menerapkan prinsip gizi seimbang dalam praktik menyusun menu sarapan, pada hari ke-2 hanya 2 kelompok $(16,7 \%)$ yang sudah menerapkan, dan pada hari ke-3 tidak ada satupun kelompok yang sudah menerapkan. Beberapa contoh menu sarapan sehat kontinental untuk anak yang dikeluarkan oleh The Crossfit Journal sebagai berikut ("Meal Plans,"
2004) meliputi (1) Quesadilla (1 tortilla jagung, 1/4 cangkir kacang hitam, 1 butir telur (diorak-arik atau digoreng), 1 ons keju, 1 sendok makan alpukat); (2) Sandwich (1/2 roti pita, 1 butir telur (diorak-arik atau digoreng), 1 ons keju, disajikan dengan 2 kacang macadamia); (3) Salad Buah (1/2 cangkir keju cottage dicampur, 1/4 blewah, 1/2 cangkir stroberi, 1/4 cangkir anggur, ditaburi dengan almond); (4) Smoothie (1 cangkir susu, 1 sdm bubuk protein, 1 cangkir stroberi beku, sesendok kecil kacang mete kemudian diblender bersama); (5) Oatmeal (1/3 cangkir oatmeal dimasak (sedikit berair), 1/2 cangkir anggur, 1/4 cangkir keju cottage, 1 sdt kenari, rempah dengan ekstrak vanili dan kayu manis; kemudian tambahkan: 1 sendok protein bubuk, 1/2 blewah, 1/2 cangkir keju cottage, 6 almond); (6) Steak dan Telur (1 ons steak panggang, 1 butir telur di atas roti, 1 iris roti panggang, 2/3 sdt mentega). Selain itu, juga terdapat beberapa contoh menu sarapan sehat Indonesia untuk anak yang dikeluarkan oleh Kementerian Kesehatan RI sebagai berikut (Kementerian Kesehatan Republik Indonesia, 2011) meliputi (1) Setangkap roti, telur mata sapi, sayuran, dan susu; (2) Nasi goreng, telur dadar, dan sayuran; (3) Bubur ayam dan pisang; (4) Lontong sayur, telur, dan buah; (5) Nasi uduk, ayam goreng, dan buah; (6) Mi goreng, telur, dan buah

\section{E. KESIMPULAN}

Berdasarkan hasil penelitian dapat disimpulkan bahwa keseluruhan (100\%) responden memiliki tingkat pengetahuan baik. Dari 20 pertanyaan tampak bahwa pertanyaan yang paling banyak terjawab dengan benar oleh responden adalah pertanyaan tentang cara yang dapat dilakukan untuk mengatasi anak yang susah sarapan dengan persentase sebesar $47,1 \%$. Sementara itu, sebanyak empat pertanyaan dengan jawaban benar paling banyak meliputi pertanyaan contoh menu gizi seimbang, manfaat sarapan pada anak, waktu sarapan yang baik pada anak, dan akibat jika anak kekurangan gizi dengan persentase masing-masing sebesar $100 \%$. Hampir 
keseluruhan dari 12 kelompok yang belum menerapkan prinsip gizi seimbang dalam praktik menyusun menu sarapan. Kampanye sarapan sehat khususnya mengenai sarapan harus dilaksanakan oleh semua pihak yaitu anak-anak, ibu, guru, dan tokoh masyarakat. Hal ini diperlukan agar kebiasaan sarapan selalu diterapkan sehingga asupan zat gizi dapat terpenuhi

\section{F. DAFTAR PUSTAKA}

Adnan, N., \& Muniandy, N. D. (2012). The Relationship between Mothers Educational Level and Feeding Practices among Children in Selected Kindergartens in Selangor, Malaysia: A Cross-sectional Study. Asian Journal of Clinical Nutrition, 4(2), 3952 .

https://doi.org/10.3923/ajcn.2012.3 9.52

Adolphus, K., Lawton, C. L., \& Dye, L. (2013). The effects of breakfast on behavior and academic performance in children and adolescents. Frontiers in Human Neuroscience, 7. https://doi.org/10.3389/fnhum.2013 .00425

Ariyanti. (2005). Faktor-Faktor yang Berhubungan dengan Kebiasaan Sarapan Pagi pada Siswa Sekolah Dasar di SDN Limus Nunggal III, Cileungsi, Bogor. Depok.

Balitbangkes Kemenkes RI. (2013). Riset Kesehatan Dasar, Riskesdas 2013.

Badan Penelitian Dan Pengembangan Kkesehatan Kementerian Kesehatan Republik Indonesia. (2010). RISET KESEHATAN DASAR RISKESDAS 2010 (p. 466). Jakarta: BALITBANGKES KEMENKES RI.

Budiman, \& Riyanto. (2013). Kapita Selekta Kuesioner: Pengetahuan dan Sikap dalam Penelitian Kesehatan. Jakarta: Penerbit Salemba Jakarta.

Cooper, S., Bandelow, S., \& Nevil, M. (2011). Breakfast Consumption and Cognitive Fuction in Adolescent Schoolchildren. Physio Behav., 103, 431-439.

Das, J. C. (2016). Fast Food Consumption in Children: A Review. Medical \& Clinical Reviews, 01(01). https://doi.org/ 10.21767/2471299X.1000001

Deshmukh-Taskar, P. R., Nicklas, T. A., O’Neil, C. E., Keast, D. R., Radcliffe, J. D., \& Cho, S. (2010). The Relationship of Breakfast Skipping and Type of Breakfast Consumption with Nutrient Intake and Weight Status in Children and Adolescents: The National Health and Nutrition Examination Survey 1999-2006. Journal of the American Dietetic Association, 110(6), 869-878. https://doi.org/10.1016/j.jada.2010. 03.023

Fatmah. (2015). Gerakan sarapan sehat anak sekolah (sarasehan) untuk peningkatan pengetahuan ibu tentang sarapan sehat anak sekolah. Jurnal Gizi Klinik Indonesia, 12(1), 12-19.

Hardinsyah. (2013). Analisis jenis, jumlah, dan mutu gizi konsumsi sarapan anak Indonesia. Jurnal Gizi Pangan, 8(1), 39-46.

Hien, N., \& Hoa, N. (2009). Nutritional status and determinants of malnutrition in children under three years of age in Nghean, Vietnam. Pak. J. Nutr., 8, 958-964.

Hong, R., Banta, J. E., \& Betancourt, J. A. (2006). Relationship between household wealth inequality and chronic childhood under-nutrition in Bangladesh. International Journal for Equity in Health, 5(1). https://doi.org/10.1186/1475-92765-15

Huang, C.-J., Hu, H.-T., Fan, Y.-C., Liao, Y.-M., \& Tsai, P.-S. (2010). Associations of breakfast skipping with obesity and health-related quality of life: evidence from a national survey in Taiwan. International Journal of Obesity, 34(4), 720-725. https://doi.org/10.1038/ijo.2009.285

Husaini, M. (1992). Kebiasaan Makan, Konsumsi Jajanan dan Aspek-aspek Kesehatan Murid SD. Bogor: Puslitbang Gizi Bogor.

Indrasari, A., Mutalazimah, M., Kumalasari, D., \& Buana, A. (2018). Perception and Quality of Breakfast on Primary School Children. Journal of Nutraceuticals and Herbal Medicine, 1(1), 33-39. 
Kalsum, U., \& Halim, R. (2016). Kebiasaan Sarapan Pagi Berhubungan dengan Kejadian Anemia pada Remaja di SMA Negeri 8 Muaro Jambi Ummi Kalsum \& Raden Halim. Jurnal Penelitian Universitas Jambi Seri Sains, 18(1), 9-19.

Kamal, S. (2011). Socio-economic determinants of severe and moderate stunting among under-five children of rural Bangladesh. Mal. J. Nutr, 17, 105-118.

Kawafheh, M. (2014). The Effect of Health Education Programs for Parents about Breakfast on Students' Breakfast and Their Academic Achievement in the North of Jordan. Int $J$ Adv Nurs Stud, 3(2), 84-89.

Kementerian Kesehatan Republik Indonesia. (2011). Makanan Sehat Anak Sekolah. Kemenkes RI, 17(2).

Kemenkes RI, K. K. R. I. (2014a). Pedoman Gizi Seimbang. Kemenkes RI.

Kementerian Kesehatan Republik Indonesia. (2014b). Piring Makanku: Porsi Sekali Makan. Kemenkes RI. Retrieved from gizi.depkes.go.id/wpcontent/uploads/2014/02/PGS-

PIRING-12-02-14-OK.pdf

Kuriyan, R., Thomas, T., Sumithra, S., Lokesh, D., Sheth, N., Joy, R., ... Kurpad, A. (2012). Potential Factors Related to Waist Circumference in Urban South Indian Children. Indian Pediatrics, 49, 124-128.

Mcdonell, E., Probart, C., Weirich, J., Hartman, T., \& Birkenshaw, P. (2004). School Breakfast Programs: Perceptions and Barriers. J Child Nutr Manag, 28(2).

Meal Plans. (2004). The Crossfit Journal, (21), 1-10.

Murchu, C. (2010). Effects of a Free School Breakfast Programme on School Attendance, Achievement,
Psychosocial Function, and Nutrition: a Stepped Wedge Cluster Randomised Trial. BMC Public Health, 1O(738), 1-6. NF. (2017). Indonesia Menghadapi Beban Ganda Malnutrisi. Retrieved May 8, 2018, from http://www.jurnalmedika.com/blog/1 -Indonesia-Menghadapi-BebanGanda-Malnutrisi

Pivik, R., Tennal, K., Chapman, S., \& Gu, Y. (2012). Eating Breakfast Enhances the Efficiency of Neural Networks Engaged During Mental Arithmetic in Scholl-Aged Children. Physio Behav, 106, 548-555.

Pongou, R., Ezzati, M., \& Salomon, J. (2005). Household and community socioeconomic and environmental determinants of child nutritional status in Cameroon. BMC Public Health, 6(10).

Rampersaud, G. C., Pereira, M. A., Girard, B. L., Adams, J., \& Metzl, J. D. (2005). Breakfast Habits, Nutritional Status, Body Weight, and Academic Performance in Children and Adolescents. Journal of the American Dietetic Association, 105(5), 743-760. https://doi.org/10.1016/j.jada.2005. 02.007

Sofianita, N., Arini, F., \& Meiyetriani, E. (2015). Peran Pengetahuan Gizi dalam Menentukan Kebiasaan Sarapan Anak-Anak Sekolah Dasar Negeri di Pondok Labu, Jakarta Selatan. Jurnal Gizi Pangan, 10(1), 57-62.

Yin, S., Li, N., Yan, Z., Pan, L., Lai, J., \& Zhao, X. (2009). Effects of nutritional education on improvement of nutritional knowledge of infant's mothers in rural area in China. Zhonghua Yu Fang Yi Xue Za Zhi, 43(2), 103-107 